Sonia Kozub - Skalska

Uniwersytet Ekonomiczny w Katowicach

\title{
Rola słupów i faktycznych organizatorów przestępstw karuzelowych oraz skala współpracy $z$ biegłymi sądowymi w przestępczości gospodarczej
}

\author{
THE ROLE OF SUBSTITUTED PERSONS AND REAL \\ ORGANIZERS OF CAROUSEL CRIMES AND THE SCALE \\ OF COOPERATION WITH COURT EXPERTS IN \\ ECONOMIC CRIME
}

\begin{abstract}
Jednym z mechanizmów, który znaczqco przyczynia się do istnienia luki w VAT sq oszustwa podatkowe realizowane $w$ ramach $t z w$. karuzeli podatkowej. Niestety skala tego zjawiska pokazuje, iz zarówno organy skarbowe, jak i organy ścigania nie radzq sobie z ograniczaniem tej skali. Dzieje się tak dlatego, że w prowadzonych postępowaniach często nie dochodzi do wykrycia faktycznego organizatora karuzeli VAT, co w konsekwencji powoduje, iż szuka on nowych stupów $i$ niemal natychmiast tworzy kolejnq karuzele. Zdaniem autora za taki stan rzeczy odpowiada między innymi organ podatkowy wydajacy decyzje podatkowe na stupów nie korzystajac przy tym $z$ możliwości wynikajacych wprost z art. 55 kodeksu karnego skarbowego (firmanctwo). Nie można bowiem zapominać, iż faktycznymi beneficjentami korzyści finansowych pochodzacych z oszustw podatkowych sq organizatorzy, nie zaś osoby podstawione (stupy), które w efekcie swojej roli sq bardzo nisko optacani. Wydanie decyzji podatkowej na faktycznego organizatora umożliwia realne odzyskanie start jakie ponióst budżet państwa. Ponadto wyspecjalizowane komórki zajmujace się odzyskaniem mienia, które podlegaja pod Wydziat ds. Odzyskiwania Mienia w Komendzie Gtównej Policji miatby realnq szansę na zabezpieczenie majqtku organizatora, pochodzqcego z przestępstwa. Wydaje się, iż bez zmiany podejścia organów podatkowych $i$ wspótpracy organów ścigania faktyczni organizatorzy pozostanq nadal bezkarni, a odzyskanie mienia niemal niemożliwe - mimo sprzyjajacych możliwości ustawodawczych. Do ustalania faktycznych organizatorów konieczna jest szeroka analiza schematu przestepczego procederu, a tym samym jak pokazuje praktyka bliższa wspótpraca wymiaru sprawiedliwości z bieglymi sq̨dowymi, która w efekcie przyczyni się do efektywności ustalania faktycznych organizatorów zorganizowanych grup przestępczych działajacych $w$ obszarach przestępstw karuzelowych.

Artykut stanowi kontynuacje badań podjętych przez autora w publikacji pt. Mechanizm przestęstw karuzelowych i metody ich ograniczenial.

Celem artykutu jest zwrócenie uwagi na konieczność zmiany podejścia do prowadzonego postępowania, co może realnie ograniczyć skalę przestępstw karuzelowych. Jednocześnie autor wskazuje na konieczność wykorzystania istniejqcego stanu prawnego oraz wspótpracy z bieglymi sadowymi w celu poprawy efektywności prowadzonych postępowań (czas
\end{abstract}

\footnotetext{
${ }^{1}$ Zobacz. Mechanizm przestępstw karuzelowych i metody ich ograniczenia, Zeszyty Naukowe Szkoły Głównej Gospodarstwa Wiejskiego w Warszawie Polityki Europejskie, Finanse i Marketing NR 17 (66) 2017, Warszawa, s. 145-160.
} 
trwania postepowania, ustalanie faktycznych organizatorów). Wartościa dodanq opracowania jest to, iż metody poruszone $w$ artykule nie wymagaja zmian legislacyjnych, a więc moga zostać natychmiast zastosowane $w$ praktyce. W celu przedstawienia zamierzonych celów zastosowano metody badań literaturowych oraz danych publicznych udostęnianych przez Ministerstwo Finansów, obowiqzujacych aktów prawnych. Ponadto przeprowadzono badania własne obejmujace skale wspótpracy między wymiarem sprawiedliwości, a biegtymi sqadowymi, co pozwala zweryfikować hipotezę, iż zakres tej wspótpracy w zakresie przestępczości gospodarczej jest niewystarczajacy. Zawarte $w$ artykule rozważania maja charakter zarówno teoretyczny, jak $i$ praktyczny.

Słowa kluczowe: firmanctwo, karuzele vat, organizatorzy przestępstw karuzelowych, opinie biegłych sądowych.

\section{Wstęp}

Podatek VAT stanowi przeważającą część luki w podatkach. Stanowi to realny i duży problem nie tylko dla budżetu państwa, ale również dla legalnie działających przedsiębiorstw, ponieważ zakłóca to rynkową konkurencję. Towar pochodzący $\mathrm{z}$ przestępstwa jest wprowadzany na rynek „,bez obciążeń podatkowych”, co powoduje, iż jest oferowany taniej często nawet o $42 \%$ (suma podatku dochodowego $19 \%$ oraz VAT $23 \%$ ) Ustawodawca od 1 stycznia 2017 r., wprowadził szereg przepisów mających na celu ograniczenie tego zjawiska. Jednak poza zmianami ustawowymi konieczna jest również zmiana współpracy między organami podatkowymi i organami ścigania. W prowadzonych postepowaniach już na początkowym etapie należy zmierzać do ustalenia faktycznych organizatorów karuzeli VAT, nie zaś prowadzić latami postępowanie zmierzające do wydania decyzji na „słupy”. Należy zaznaczyć, iż określenie słup nie posiada definicji legalnej. W Wielkim Stowniku Języka Polskiego ${ }^{2}$ jest natomiast zawarta następująca definicja: stup (człowiek) -pot. osoba, która firmuje swoim nazwiskiem jakieś działanie, $w$ celu ukrycia faktycznego inspiratora lub uczestnika. W literaturze (m.in. u Brunona Hołysta) w odniesieniu do firm słupów posługiwano się określeniem firmy firmanckie ${ }^{3}$. Taką również definicję przyjeto na potrzeby niniejszego artykułu.

Działanie takie pomoże podnieść efektywność prowadzonych postępowań skracając ich trwanie z 6 lat do 1 roku. Ponadto ustalanie faktycznych organizatorów od początku postępowania pozwoli na zabezpieczenie mienia beneficjentów korzyści finansowych pochodzących $\mathrm{z}$ przestępstwa, a tym samym odzyskanie strat, które poniósł budżet państwa. Zaniechanie ustalania faktycznych organizatorów powoduje, iż prowadzone latami postepowania karne $\mathrm{w}$ gruncie rzeczy są nieefektywne, ponieważ słup nie posiada majątku, a więc budżet państwa nie odzyskuje wyłudzonego podatku, a faktyczny organizator pozostaje bezkarny i często tworzy kolejne karuzele. Praktyka pokazuje również, iż biegły sądowy jest rzadko lub zbyt późno powoływany do opiniowania w zakresie schematu i skali konkretnego przestępstwa karuzelowego, co w efekcie prowadzi do braku odzyskania należności publicznoprawnych $\mathrm{z}$ uwagi na ich przedawnienie, a w konsekwencji postępowania są prowadzone tylko pod kątem przestępstw wynikających z art. 258 i 299 kodeksu karnego ${ }^{4}$ (udział w zorganizowanej

\footnotetext{
${ }^{2}$ Dz.U.UE L 331/13 z 5XI 2004.

${ }^{3}$ B. Hołyst, Kryminalistyka, Warszawa 2007, LexisNexis, s. 296-303.

${ }^{4}$ Ustawa z dnia 6 czerwca 1997 r. Kodeks karny. (t.j. Dz. U. z 2016 r. poz. 1137 z późn. zm.).
} 
grupie przestępczej, pranie pieniędzy). Należy również wspomnieć, iż mimo możliwości płynących $\mathrm{z}$ art. 44 a oraz art. 45 kodeksu karnego ${ }^{5}$ wyspecjalizowane komórki ds. Odzyskania Mienia działające przy Wydziale ds. Odzyskania Mienia w Komendzie Głównej Policji pozostają bezradne, ponieważ sposób prowadzenia przestępstw karuzelowych determinuje ich do poszukiwania majątku ,słupów” nie zaś faktycznych organizatorów. Wprowadzenie procedur zbierania i zabezpieczania materiału dowodowego oraz prowadzenie analiz kryminalnych do postępowań dotyczących przestępstw karuzelowych ${ }^{6}$ oraz ustalanie od początku postepowania faktycznych organizatorów zgodnie $\mathrm{z}$ art. 55 kodeksu karnego skarbowego ${ }^{7} \mathrm{w}$ sposób rzeczywisty ograniczy skalę zjawiska tego rodzaju przestępczości gospodarczej. Praktyka pokazuje również, iż rola biegłych sądowych $\mathrm{w}$ postepowaniach dotyczących przestępstw gospodarczych jest wciąż niewystarczająca, a ich udział włączany jest zbyt późno. W artykule zaprezentowano skalę współpracy biegłych sądowych $\mathrm{z}$ wymiarem sprawiedliwości $\mathrm{w}$ kontekście przestępstw opisanych w rozdziale XXXVI kodeksu karnego. Dobrana próba badawcza skupiająca się na konkretnym rozdziale kodeksu karnego uzasadniona jest tym, iż zawiera on katalog przestępstw najczęściej występujących $\mathrm{w}$ zorganizowanych grupach przestępczych dokonujących oszustw podatkowych. W Polsce nie istnieje jednolity system rejestracji prowadzonych postępowań i dochodzeń, co determinowało dobór próby badawczej w ten sposób, aby wszystkie jednostki objęte badaniem dysponowały danymi statystycznymi niezbędnymi do udzielenia odpowiedzi w trybie informacji publicznej.

Celem artykułu jest zwrócenie uwagi na konieczność zmiany podejścia do prowadzonego postępowania, co może realnie ograniczyć skalę przestępstw karuzelowych. Jednocześnie autor wskazuje na konieczność wykorzystania istniejącego stanu prawnego oraz współpracy z biegłymi sądowymi w celu poprawy efektywności prowadzonych postępowań (czas trwania postepowania, ustalanie faktycznych organizatorów). Wartością dodaną opracowania jest to, iż metody poruszone w artykule nie wymagają zmian legislacyjnych, a więc mogą zostać natychmiast zastosowane w praktyce. W celu przedstawienia zamierzonych celów zastosowano metody badań literaturowych oraz danych publicznych udostępnianych przez Ministerstwo Finansów, obowiązujących aktów prawnych. Ponadto przeprowadzono badania własne obejmujące skalę współpracy między wymiarem sprawiedliwości, a biegłymi sądowymi, co pozwala zweryfikować hipotezę, iż zakres tej współpracy w zakresie przestępczości gospodarczej jest niewystarczający. Zawarte $\mathrm{w}$ artykule rozważania mają charakter zarówno teoretyczny, jak i praktyczny.

\section{Charakterystyka przestępstw karuzelowych}

W literaturze, wyrażenie "karuzela" odnosi się do sposobu, w jaki sprzedawane towary krążą między poszczególnymi podmiotami zaangażowanymi (świadomie bądź nie) w przestępczy łańcuch dostaw. W szczególności z karuzelą podatkową mamy do

\footnotetext{
${ }_{6}^{5}$ Ibidem

${ }^{6}$ szerzej. S. Kozub- Skalska: Mechanizm przestępstw karuzelowych $i$ metody ich ograniczenia, Zeszyty Naukowe Szkoły Głównej Gospodarstwa Wiejskiego w Warszawie Polityki Europejskie, Finanse i Marketing nr 17 (66) 2017, Warszawa, s. 145-160.

${ }^{7}$ Ustawa z dnia 10 września 1999 r. Kodeks karny skarbowy. (t.j. Dz. U. z 2016 r. poz. 2137 z późn. zm.).
} 
czynienia wtedy, gdy w wyniku szeregu transakcji sprzedażowych produkty "wracają" do pierwszego ogniwa w łańcuchu. Zaznacza się, jednakże, że element ten w żadnym razie nie stanowi warunku koniecznego dla popełnienia zorganizowanego oszustwa podatkowego. $Z$ tego względu, dla celów ujęcia całości zjawiska można też posługiwać się zbiorczym pojęciem "zorganizowanego oszustwa VAT" rozumianego jako "oszustwo popełniane za pomocą różnorodnych metod, nakierowane na uzyskanie nienależnej korzyści związanej z rozliczeniami z zakresu VAT, z użyciem powiązań pomiędzy podmiotami działającymi w skali międzynarodowej"'. . Oszustwo karuzelowe bazuje na takim przepływie towarów pomiędzy państwami członkowskimi, który skutkuje powrotem towarów do państwa ich pierwotnego pochodzenia i ma na celu uchylenie się od opodatkowania, legalizację towarów nabytych nielegalnie czy sprzedaż towarów po cenach niższych niż ceny rynkowe ${ }^{9}$. Podkreślenia wymaga, że nieodłącznym elementem oszustwa typu karuzelowego jest występowanie tzw. znikającego podatnika, czyli podmiotu, który dokonuje rejestracji na potrzeby VAT "fikcyjnego" przedsiębiorstwa, w celu uniknięcia zapłaty podatku od towarów i usług należnego (wskutek niedopełnienia obowiązku zadeklarowania części lub całości obrotu dokonywanego przez dany podmiot), albo wyłudzenia podatku od towarów i usług naliczonego wynikającego $\mathrm{z}$ upozorowania transakcji krajowych lub wewnątrzwspólnotowych.

Jak pokazuje praktyka, podmioty - dokonujące rejestracji na potrzeby podatku od towarów i usług tylko w celu dokonania oszustwa podatkowego - często posługują się danymi niezgodnymi ze stanem faktycznym, poprzez np. wskazywanie fałszywego adresu. Rejestracji dokonuje najczęściej osoba, która w rzeczywistości nie kieruje działalnością podmiotu, nie posiada wiedzy na temat planowanych transakcji czy też informacji o osobach faktycznie kierujących działalnością podmiotu, nie posiada dostępu do rachunku bankowego firmowanego przez siebie podmiotu. Stąd też często dla określenia takich podmiotów używana jest nazwa "spółki-wydmuszki", "spółkisłupa", które po wyeksploatowaniu zastępowane są kolejnymi. Znikający podatnik jest więc kluczowym elementem w znanych obecnie konstrukcjach karuzelowych jako podmiot (teoretycznie jedyny), który nie wypełnia swoich zobowiązań w zakresie podatku od towarów i usług. Nadana mu przez doktrynę zachodnioeuropejską nazwa odnosi się do charakterystycznej dla modus operandi przestępstw karuzelowych przerwy w łańcuchu dostaw opodatkowanych podatkiem od wartości dodanej, powstałej za sprawą jednego z zaangażowanych weń podatników, który znika pozostawiając po sobie nieuregulowane kwoty podatku należnego, który jest następnie zgodnie $\mathrm{z}$ prawem odliczany przez kolejnego handlowca $\mathrm{w}$ łańcuchu. W praktyce znikający podatnik korzysta z możliwości sprowadzania towarów "wolnych od VAT" z innych krajów członkowskich UE. Co oczywiste, nie wykazuje on podatku w państwie przeznaczenia, niemniej jednak dokonuje dalszej dostawy produktów w obrębie jego terytorium na rzecz podatników prowadzących tam swoją działalność. Dostawy te dokumentowane są fakturami VAT, lecz wykazane $\mathrm{w}$ nich kwoty podatku należnego nigdy nie są

\footnotetext{
${ }^{8}$ T. Pabiański, W. Śliz: Zorganizowane działania przestępcze wykorzystujące mechanizmy konstrukcyjne podatku VAT, Przegląd Podatkowy, 1/2007.

${ }^{9}$ M. Keen, S. Smith: VAT Fraud and Evasion: What Do We Know, and What Can be Done?, IMF Working Paper 2007, s. 13, za: R. Lipniewicz: Docelowy system VAT w Unii Europejskiej. Harmonizacja opodatkowania transakcji wewnątrzwspólnotowych, Oficyna 2010, lex/El.
} 
regulowane ${ }^{10}$. Typowy łańcuch transakcji w przestępstwach karuzelowych przedstawia rysunek 1.

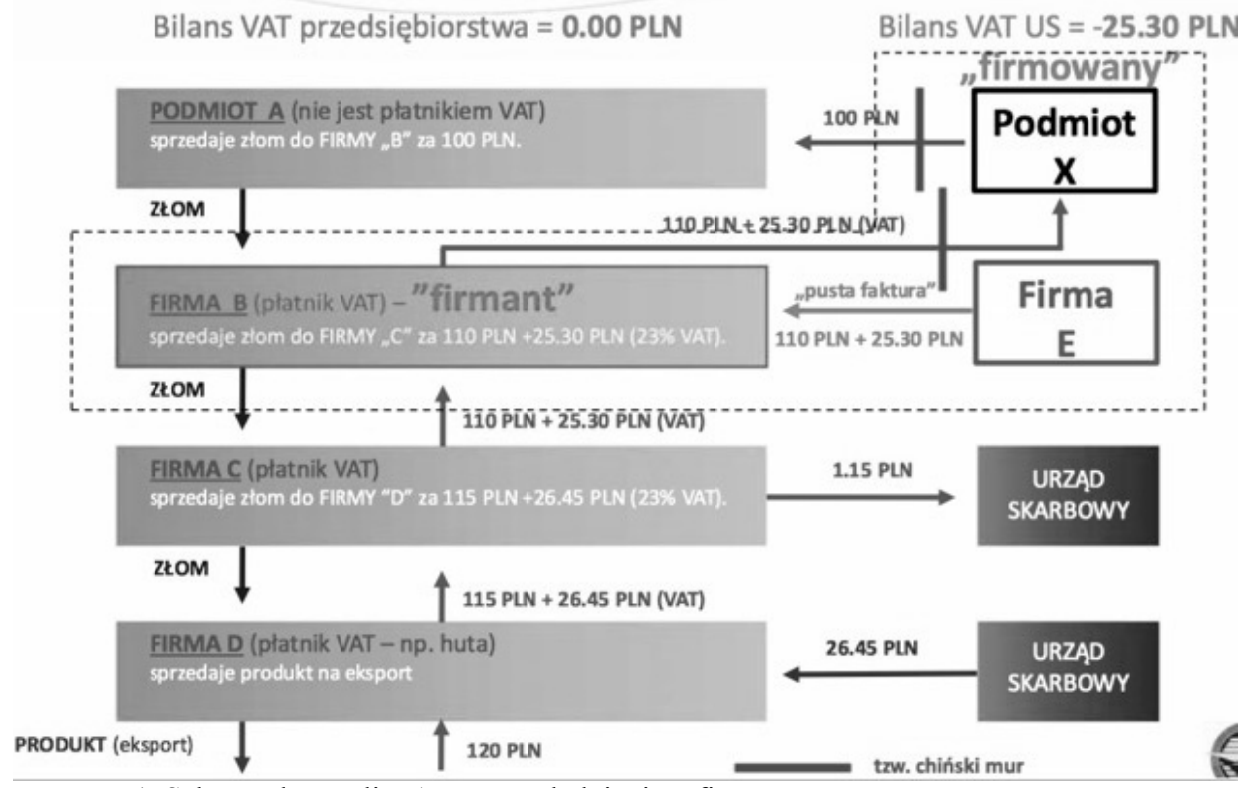

Rysunek 1. Schemat karuzeli VAT z uwzględnieniem firmanctwa.

Źródło. Mechanizm „firmanctwa” w obrocie gospodarczym w polskim systemie podatkowym przedstawiony przez Izbę Gospodarczą Metali Nieżelaznych i Recyklingu Komisji Ustawodawczej Senatu Rzeczpospolitej Polskiej z dnia 15 listopad 2012 r.

Konkludując powyższe rozważania należy zwrócić szczególną uwagę na konieczność przypisywania konkretnych ról poszczególnym uczestnikom przestępstw karuzelowych, ponieważ tylko takie działanie pozwoli otworzyć schemat karuzeli zawarty w rysunku 1. Rysunek ten w czytelny sposób pokazuje rolę „firmanta” oraz „firmowanego", co w efekcie pozwala faktycznemu organizatorowi na czerpanie korzyści finansowych z zorganizowanej przestępczości gospodarczej. Konsekwencje nieustalania „firmanta” dla budżetu państwa są ogromne, ponieważ powszechnie wiadomo, iż słup nie ma żadnego majątku natomiast bez wykorzystania art. 55 kodeksu karnego skarbowego Wydziały ds. Odzyskiwania Mienia działające w każdej Komedzie Wojewódzkiej Policji nie mają podstaw prawnych do zabezpieczenia majątku faktycznego organizatora, czyli głównego beneficjenta uzyskującego korzyści finansowych z oszustw podatkowych. Ponieważ artykuł stanowi kontynuacje badań podjętych przez autora w publikacji pt. Mechanizm przestępstw karuzelowych i metody

\footnotetext{
${ }^{10}$ Wyrok Wojewódzkiego Sądu Administracyjnego w Warszawie z dnia 3 lutego 2017 r. III SA/Wa 3363/15 Znikający podatnik, bufor i broker w karuzeli podatkowej.
} 
ich ograniczenia ${ }^{11} \mathrm{w}$ niniejszej pracy skupiono się tylko na roli słupa oraz faktycznego organizatora. Rozważania dotyczące pozostałych ról zostały opisane w przywołanym artykule.

\section{Charakterystyka słupów}

Analizując postępowania dotyczące zorganizowanych grup przestępczych dopuszczających się oszustw podatkowych można wyodrębnić cechy charakterystyczne dla „słupów”. Wśród najczęściej spotykanych rodzajów słupów można wymienić:

- Osoba fizyczna będąca jednocześnie udziałowcem i prezesem spółki z ograniczoną odpowiedzialnością,

- Osoba fizyczna prowadząca działalność gospodarcza w swoim imieniu.

Co charakterystyczne osoby te nigdy nie podejmuja decyzji samodzielnie w zakresie prowadzonej przez siebie działalności gospodarczej, a jedynie wykonują polecenia innych osób $^{12}$. Ciekawe badanie w zakresie cech charakterystycznych dla słupów przeprowadził Kamil Nowak na podstawie analizy postępowań przygotowawczych prowadzonych przez Delegaturę ABW w Katowicach - dotyczących zorganizowanych grup przestępczych zajmujących się oszustwami podatkowymi w latach 2008-2013. Wykres 1 przedstawia zestawienie wszystkich cech charakterystycznych dla słupów w latach 2008-2013. Udział procentowy odnosi się do całego badanego okresu.

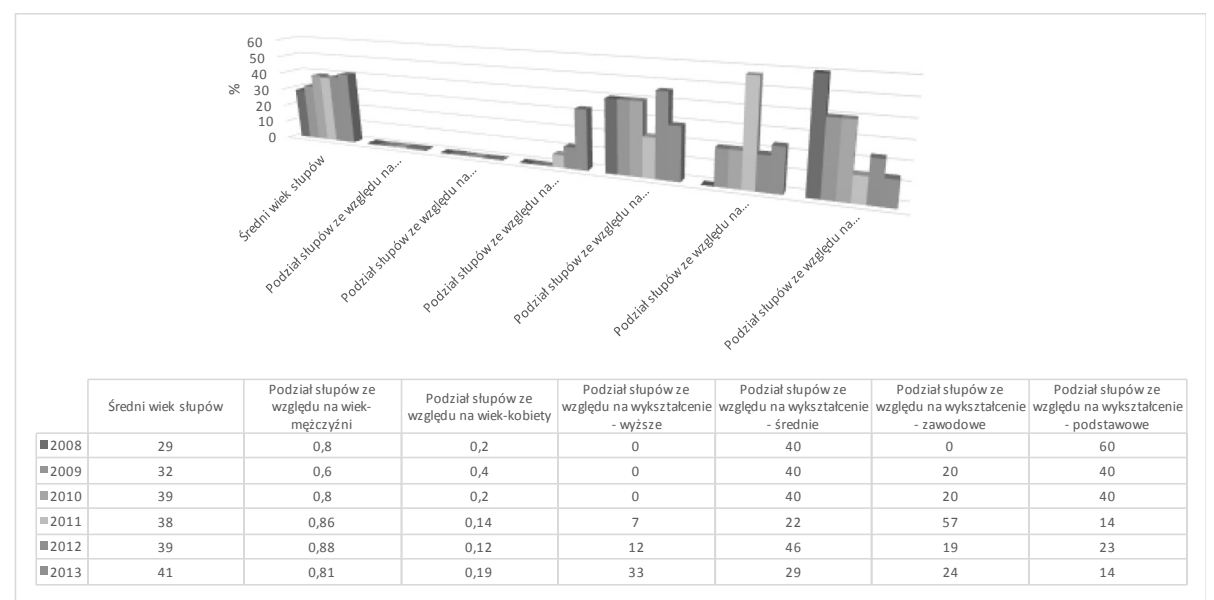

Wykres 1. Cechy charakterystyczne słupów w latach 2008-2013.

\footnotetext{
${ }^{11}$ Zobacz. Mechanizm przestępstw karuzelowych i metody ich ograniczenia, Zeszyty Naukowe Szkoły Głównej Gospodarstwa Wiejskiego w Warszawie Polityki Europejskie, Finanse i Marketing NR 17 (66) 2017, Warszawa, s. 145-160.

${ }^{12}$ K. Nowak: Wybrane zagadnienia dotyczące działalności tzw. słupów w ramach zorganizowanych grup przestępczych dopuszczających się oszustw podatkowych w związku z obrotem wyrobami stalowymi. Przegląd Bezpieczeństwa Wewnętrznego nr 6, Warszawa 2014, s. 172.
} 
Źródło. Opracowanie własne na podstawie K. Nowak: Wybrane zagadnienia dotyczące działalności tzw. słupów w ramach zorganizowanych grup przestępczych dopuszczających się oszustw podatkowych w związku z obrotem wyrobami stalowymi. Przegląd Bezpieczeństwa Wewnętrznego nr 6, Warszawa 2014, s. 177-178.

$\mathrm{Z}$ analizy wykresu 1 można wywnioskować, iż słup to najczęściej osoba w średnim wieku, przeważnie mężczyzna, najczęściej z wykształceniem podstawowym lub zawodowym. Ponadto $\mathrm{z}$ całą pewnością to osoba, która nie prowadzi faktycznej działalności gospodarczej w swoim imieniu, a jedynie wykonuje polecenia innych osób (organizatorów przestępstwa). Należy więc stwierdzić, iż słup w rzeczywistości pełni rolę „firmującego".

Słupom przedstawiano najczęściej zarzuty popełnienia przestępstw z art. $258 \mathrm{kk}$ (udział w grupie przestępczej) - 99 proc., z art. 299 kk (pranie pieniędzy) - 91 proc., z art. $76 \mathrm{kks}$ (narażenie na bezpodstawny zwrot podatku) - 50 proc., z art. $286 \mathrm{kk}$ (oszustwo) 42 proc., rzadziej $\mathrm{z}$ innych artykułów Kodeksu karnego lub Kodeksu karnego skarbowego. Zdecydowanej większości słupów przedstawiono zarzuty popełnienia przestępstw z kilku artykułów Kodeksu karnego i Kodeksu karnego skarbowego ${ }^{13}$. Prawie w ogóle nie postawiono zarzutów z tytułu art. 55 kodeksu karnego skarbowego ${ }^{14}$, czyli firmanctwa, a więc nie dążono do postawienia zarzutów faktycznemu organizatorowi. Wnioski te potwierdza analiza postawionych zarzutów w Delagatorze ABW w Katowicach w latach 2008-2013 przedstawiona na wykresie 2. Podobne wnioski można wysunąć dokonując analizy postawionych zarzutów w Komendzie Wojewódzkiej Policji w Krakowie w latach 2014-2016 przedstawiona na wykresie 3. Z uwagi na fakt, iż badane jednostki nie gromadzą w sposób jednolity danych statystycznych dotyczących przestępstw gospodarczych autor poglądowo przedstawia dane jednostki, z której otrzymał w ramach informacji publicznej szczegółowy wykaz z jakiego artykułu zostały postawione zarzuty. $\mathrm{W}$ połaczeniu jednak $\mathrm{z}$ badaniem przeprowadzonym przez $\mathrm{K}$. Nowak dane te pozwalają na wyciągnięcie $\mathrm{z}$ ich analizy wniosków. Dane zawarte w wykresie 1 i 2 zawierają udział \% w całym badanym okresie.

\footnotetext{
${ }^{13}$ K. Nowak: Wybrane zagadnienia dotyczące działalności tzw. słupów w ramach zorganizowanych grup przestępczych dopuszczających się oszustw podatkowych w związku z obrotem wyrobami stalowymi. Przegląd Bezpieczeństwa Wewnętrznego nr 6, Warszawa 2014, s. 180.

${ }^{14}$ Ustawa z dnia 10 września 1999 r. Kodeks karny skarbowy. (t.j. Dz. U. z 2016 r. poz. 2137 z późn. zm.).
} 


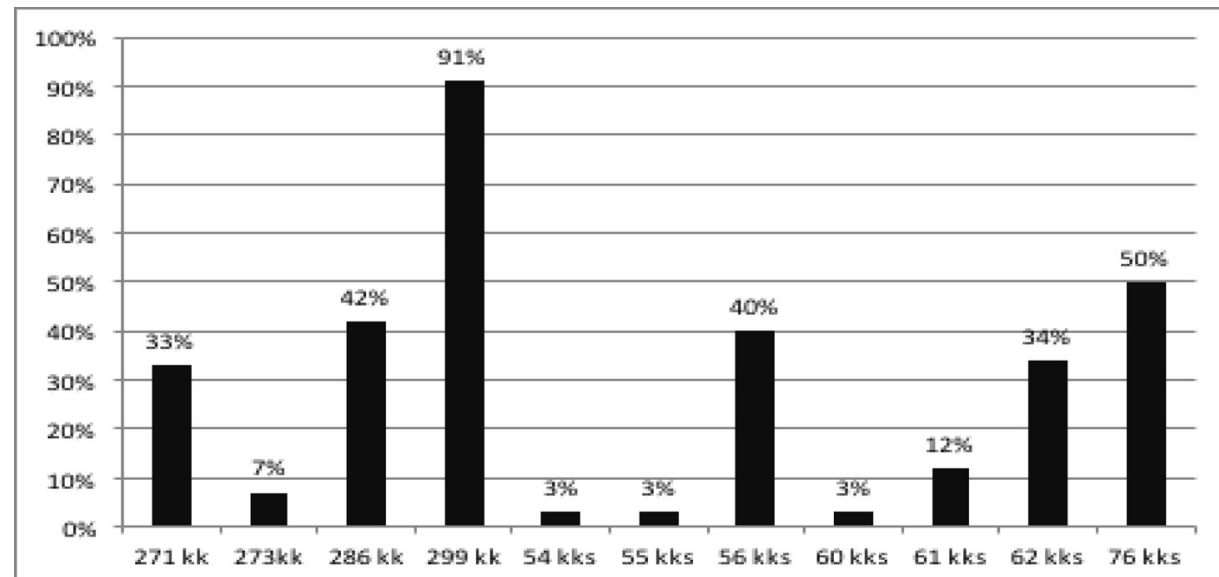

Wykres 2. Podział pod kątem przedstawionych słupom zarzutów (w proc.) lata 2008$-2013$.

Źródło. K. Nowak: Wybrane zagadnienia dotyczące działalności tzw. słupów w ramach zorganizowanych grup przestępczych dopuszczających się oszustw podatkowych w związku z obrotem wyrobami stalowymi. Przegląd Bezpieczeństwa Wewnętrznego nr 6, Warszawa 2014, s. 180.

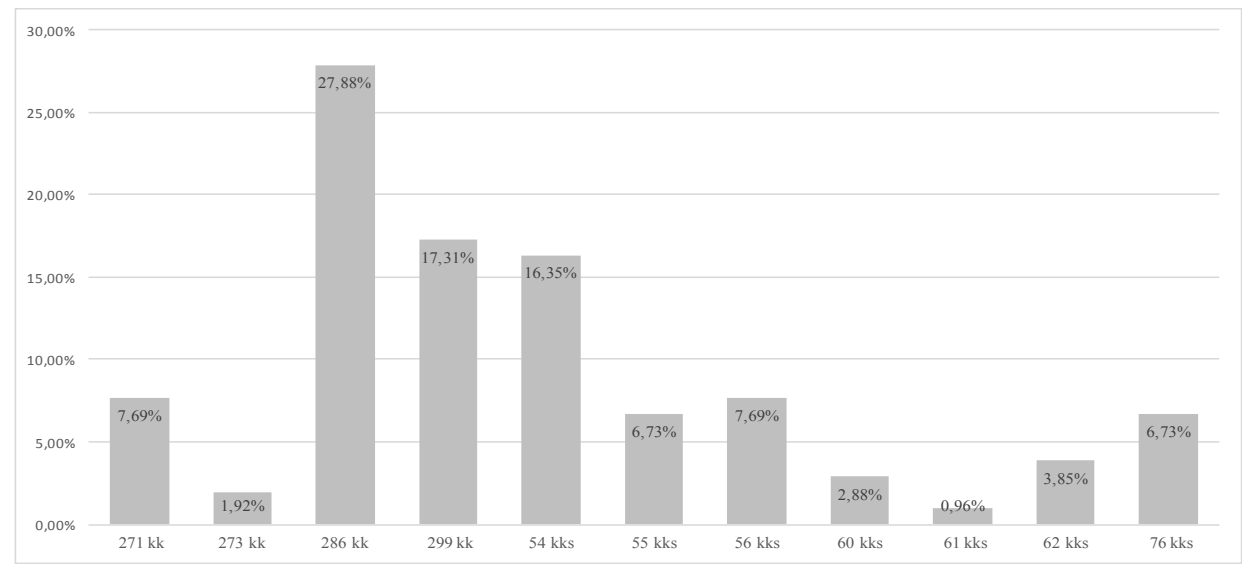

Wykres 3. Podział pod kątem przedstawionych zarzutów (w proc.) lata 2014-2016.

Źródło. Opracowanie własne na podstawie danych otrzymanych w ramach dostępu do informacji publicznej z Komendy Wojewódzkiej Policji w Krakowie.

Analizując wykres 2 z łatwością można zobaczyć, iż mimo faktu, że słup nie prowadzi faktycznej działalności gospodarczej we własnym imieniu oraz wykonuje polecenia innych osób to w latach 2008-2013 tylko 3\% zarzutów dotyczyło art. 55 kodeksu karnego skarbowego (firmanctwa). Natomiast analiza wykresu 3 pokazuje, iż w latach 2014-2016 tylko 6,73\% dotyczyło art. 55 kodeksu karnego skarbowego (firmanctwa). Zważywszy na specyfikę przestępstw karuzelowych nie jest to wynik wystarczający. Do ustalania faktycznych organizatorów konieczna jest współpraca z 
biegłymi sądowymi na początkowym etapie postępowania. Praktyka pokazuje, iż skala tej współpracy jest niewystarczająca.

\section{Firmanctwo}

W przepisie art. 55 kodeksu karnego skarbowego ${ }^{15}$ uregulowana jest odpowiedzialność karna skarbowa za tzw. firmanctwo. Jest to zachowanie podatnika, który w celu zatajenia prowadzenia działalności gospodarczej na własny rachunek lub rzeczywistych rozmiarów tej działalności posługuje się imieniem i nazwiskiem, nazwą lub firmą innego podmiotu i przez to naraża podatek na uszczuplenie ${ }^{16}$. Czyny takie nazywane sa firmanctwem podatkowym ${ }^{17}$. Zachowanie firmanta zawsze musi polegać na działaniu, ze względu na użycie w przepisie art. 55 kodeksu karnego skarbowego znamienia czasownikowego „posługuje się" ${ }^{18}$. Powstaje jednak kwestia ewentualnej odpowiedzialności "firmującego" to znaczy podmiotu, którego imieniem i nazwiskiem, nazwą lub firmą posłużył się firmant. Przepis art. 55 kodeksu karnego skarbowego jest odpowiednikiem dawnego art. 93 uks, na podstawie którego, tej samej karze, jak firmant podlegał także „firmujący”, to znaczy ten, kto dopuszczał do posługiwania się jego nazwiskiem lub firma, albo pełniąc funkcję $w$ instytucji dopuszczał do posługiwania się nazwą tej instytucji przez firmanta. To pominięcie odpowiedzialności firmującego nie oznacza i nie przesądza automatycznie, że firmujący odpowiedzialności żadnej nie ponosi. Firmanctwo niesie za sobą również konsekwencje podatkowe, przewidziane w art. 113 ordynacji podatkowej ${ }^{19}$, który stanowi, że jeżeli podatnik, za zgodą innej osoby, w celu zatajenia prowadzenia działalności gospodarczej lub rzeczywistych rozmiarów tej działalności, posługuje się lub posługiwał się imieniem i nazwiskiem, nazwą lub firmą tej osoby, osoba ta ponosi solidarną odpowiedzialność z podatnikiem całym swoim majątkiem za zaległości podatkowe powstałe podczas prowadzenia tej działalności ${ }^{20}$. Odpowiedzialność podatkowa osób trzecich związana $\mathrm{z}$ firmanctwem ma w pewnym stopniu charakter sankcji skierowanej przeciwko osobie, zezwalającej na posługiwanie się imieniem i nazwiskiem, nazwą lub firmą (osoba firmująca) innej osoby (osoba firmowana) w celu obejścia prawa podatkowego ${ }^{21}$. Wobec organów podatkowych podatnikiem jest ten, kto rzeczywiście prowadzi działalność gospodarczą (firmowany), a

\footnotetext{
${ }^{15}$ Ustawa z dnia 10 września 1999 r. Kodeks karny skarbowy. (t.j. Dz. U. z 2016 r. poz. 2137 z późn. zm.).

${ }^{16}$ L. Wilk: Firmanctwo - art. 55 kodeksu karnego skarbowego, Prok. i Pr. 2001 nr 6.

${ }^{17}$ S. Baniak: Prawo karne skarbowe, Warszawa 2006, s. 223.

${ }^{18}$ L. Wilk: Przestepstwa i wykroczenia skarbowe [w:] Prawo gospodarcze i handlowe. Tom. 10. Prawo karne gospodarcze, pod redakcją O. Górniok, Warszawa 2003, s.569.

${ }^{19}$ Ustawa z dnia 29 sierpnia 1997 r. - Ordynacja podatkowa. (t.j. Dz. U. z 2017 r. poz. 201 z późn. zm.).

${ }^{20}$ Zob. szerzej m.in. D. Zalewski, Odpowiedzialność za firmanctwo, Monitor Podatkowy $2009 \mathrm{nr} 4$, s. 25-30; R. Mastalski [w:] B. Adamiak, J. Borkowski, R. Mastalski, J. Zubrzycki, Ordynacja podatkowa. Komentarz 2004, Wrocław 2004, s. 422-423; S. Babiarz [w:] S. Babiarz, B. Dauter, B. Gruszczyński, R. Hauser, A. Kabat, M. Niezgódka-Medek, Ordynacja podatkowa. Komentarz, Warszawa 2004, s. 393; A. Olesińska [w:] B. Brzeziński, M. Kalinowski, M. Masternak, A. Olesińska, Ordynacja podatkowa. Komentarz, Toruń 2002, s. 403; w literaturze podatkowej dotyczącej firmanctwa dla osoby, która rzeczywiście prowadzi działalność gospodarczą używa się określenia „firmowany” lub „osoba firmowana”. Określenie to jest odpowiednikiem pojęcia „fir- manta” używanego w literaturze karnoskarbowej.

${ }^{21}$ R. Mastalski [w:] B. Adamiak, J. Borkowski, R. Mastalski, J. Zubrzycki: Ordynacja podatkowa. Komentarz 2004, Wrocław 2004, s. 422.
} 
osobą trzecią jest firmujacy, na którym jednak nie ciąży obowiązek podatkowy ${ }^{22}$. W przypadku, gdy podatnik, za zgodą innej osoby, w celu zatajenia działalności gospodarczej lub rzeczywistych jej rozmiarów, posługuje się lub posługiwał imieniem i nazwiskiem, nazwą lub firmą tej osoby, osoba ta ponosi solidarną odpowiedzialność z podatnikiem całym swoim majątkiem za zaległości podatkowe powstałe podczas prowadzenia tej działalności ${ }^{23}$. W przeciwieństwie do zachowania firmanta zachowanie firmującego moze polegać zarówno na działaniu (np. dostarczenie dokumentów, pieczątek swojej firmy firmantowi), jak i na zaniechaniu (gdy firmujący wiedząc, że firmant posługuje sie jego nazwiskiem lub firma dopuszcza do tego i nic nie czyni, aby przerwać ten stan niezgodny $\mathrm{z}$ prawem $)^{24}$. Zjawiskowa forma pomocnictwa znana $\mathrm{w}$ prawie karnym powszechnym (art. $18 \S 3 \mathrm{kk}$ ) jest przyjęta w prawie karnym skarbowym tylko w zakresie przestępstw skarbowych (art. $20 § 2 \mathrm{kks}$ ), nie występuje zaś w przypadku wykroczeń skarbowych, natomiast firmanctwo z art. 55 kodeksu karnego skarbowego, jest tzw. „przepołowionym typem” czynu zabronionego, tzn. takim, w którym wysokość kwoty podatku narażanego na uszczuplenie decyduje o rozgraniczeniu przestępstwa od wykroczenia ${ }^{25}$. Zatem, gdyby firmującego uznać za pomocnika, to oznaczałoby, że ponosiłby odpowiedzialność za pomoc firmantowi pod warunkiem, że kwota podatku narażonego na uszczuplenie przekracza tzw. ustawowy próg, czyli pięciokrotną wysokość najniższego miesięcznego wynagrodzenia w czasie popełnienia czynu zabronionego (art. $53 \S 3$ i $6 \mathrm{kks})^{26}$. W zorganizowanej działalności przestępczej dotyczącej oszustw podatkowych kwoty te zawsze znacznie przekraczaja pięciokrotną wysokość najniższego miesięcznego wynagrodzenia w czasie popełnienia czynu zabronionego, a więc dochodzi do ustalenia faktycznych konsekwencji zarówno dla słupa, który się godził i miał świadomość w jakim celu jest używana jego firma, jak również konsekwencji dla faktycznego organizatora, który czerpał największe korzyści finansowe z popełnionego oszustwa podatkowego. Do realizacji celu jakim jest ustalenie faktycznego organizatora przestępstwa karuzelowego niezbędna jest współpraca wymiaru sprawiedliwości $\mathrm{i}$ organów podatkowych $\mathrm{z}$ biegłymi sądowymi na początkowym etapie prowadzonych postępowań. Pozwoli to na realne odzyskanie należności publicznoprawnych od faktycznych beneficjentów korzyści podatkowych, a nie prowadzenie nieefektywnych postępowań tylko w oparciu o art. 258 oraz 299 kodeksu karnego (zorganizowane grupy przestępcze, pranie pieniędzy). Należy również zaznaczyć, iż prowadzenie postępowania w kontekście art. 299 kodeksu karnego jest wygodne $\mathrm{z}$ punktu widzenia wymiaru sprawiedliwości, ponieważ przestępstwa te nie ulegają przedawnieniu. Z punktu widzenia Budżetu Państwa są one zaś zupełnie nieefektywne, ponieważ dochodzi do przedawnienia należności publicznoprawnych a

\footnotetext{
${ }^{22}$ S. Babiarz, B. Dauter, B. Gruszczyński, R. Hauser, A. Kabat, M. Niezgódka-Medek: Ordynacja

podatkowa. Komentarz, Warszawa 2004, s. 393.

${ }^{23}$ R. Mastalski [w:] B. Adamiak, J. Borkowski, R. Mastalski, J. Zubrzycki: Ordynacja podatkowa. Komentarz 2003, Wrocław 2003, s. 422-423.

${ }^{24}$ L. Wilk: Przestepstwa i wykroczenia skarbowe [w:] Prawo gospodarcze i handlowe. Tom. 10.

Prawo karne gospodarcze, pod redakcją O. Górniok, Warszawa 2003, s. 569-570.

${ }^{25}$ L. Wilk: Firmanctwo - art. 55 kodeksu karnego skarbowego, Prok. i Pr. 2001 nr 6, s. 62-63.

${ }^{26}$ L. Wilk: Firmanctwo - art. 55 kodeksu karnego skarbowego, Prok. i Pr. 2001 nr 6, s. 63.
} 
ponadto do pozostawienia majątku pochodzącego $\mathrm{z}$ przestępstwa $\mathrm{u}$ faktycznego organizatora, co prowadzi do całkowitej bezkarności i pogłębienia strat dla finansów publicznych państwa.

\section{Współpraca biegłych sądowych z wymiarem sprawiedliwości w postępowaniach dotyczących przestępstw gospodarczych}

Praktyka pokazuje, iż zarówno wymiar sprawiedliwości, jak i organy podatkowe zbyt późno i w zbyt małym zakresie sięgają po pomoc biegłego sądowego w sprawach dotyczących zorganizowanych grup przestępczych $\mathrm{w}$ tym dokonujących przestępstw karuzelowych. Tymczasem należy zauważyć, iż biegły sądowy z natury rzeczy jest organem pomocniczym wymiaru sprawiedliwości i stanowi instytucję sądowego prawa procesowego. $Z$ uwagi na swą rolę oceniającą i rozstrzygającą biegły zbliża się do funkcji sędziego. Podobnie jak sędzia, musi rozstrzygać przedstawione mu kwestie na podstawie wiedzy specjalnej i zgodnie z jej zasadami podobnie jak sędzia, musi on również $\mathrm{w}$ zasadzie przeprowadzić $\mathrm{w}$ tym celu odpowiednie badanie, połączone niejednokrotnie $\mathrm{z}$ dokonaniem własnych ustaleń na podstawie prowadzonych czasem przez biegłych sui generis postępowań dowodowych. Stąd też jego świadectwo ma podobną strukturę logiczna jak orzeczenie sądowe (stwierdzenie faktów). Biegły musi także ten materiał skonfrontować $\mathrm{z}$ właściwymi zasadami naukowymi oraz wyciągnąć stąd odpowiednie wnioski, będące rozstrzygnięciem kwestii specjalnej stanowiącej przedmiot postępowania. Ponadto opinia biegłego na równi $\mathrm{z}$ innymi środkami dowodowymi podlega swobodnej ocenie organów procesowych oraz kontradyktoryjnej kontroli stron $\mathrm{w}$ postępowaniu dowodowym ${ }^{27}$. Jest więc oczywistym, iż wymiar sprawiedliwości prowadząc postepowania dotyczące przestępczości gospodarczej (ekonomicznej) ma możliwość korzystania z opinii biegłych sądowych i na podstawie tych opinii ocenić, czy możliwym jest zakończenie postępowania (umorzenie lub postawienie zarzutów). Wydaje się to ważne szczególnie w zorganizowanych grupach przestępczych dokonujących oszustw podatkowych, gdzie na podstawie zebranego i zabezpieczonego materiału dowodowego biegły jako swoisty łącznik wiedzy między organem podatkowym specjalizującym się w prawie podatkowym, a organami ścigania specjalizującymi się W zorganizowanej przestępczości przeprowadzi analizę ekonomiczno-kryminalną powiązań kapitałowo osobowych (uczestników grupy i ich ról), wskaże faktycznych organizatorów, jak również wyliczy kwotę na jaką dokonano przestępstwa. Biegły jest osobowym źródłem dowodowym posiadającym wiadomości specjalne. Jego opinia stanowi szczególny samoistny środek dowodowy ${ }^{28}$. Posiada wiadomości specjalne tj. wiedza ekonomiczna poparta doświadczeniem uczestnictwa w postępowaniach karnych dotyczących przestępstw gospodarczych, czego organy podatkowe w swojej codzienności mają znacznie mniej, a więc biegły stanowi uzupełnienie wiedzy podatkowej i karnej przestępstwach gospodarczych zorganizowanych grup przestępczych.

W celu oceny skali współpracy biegłych sądowych $\mathrm{z}$ wymiarem sprawiedliwości przeprowadzono badanie wysyłając $w$ ramach ustawy $z$ dnia 6 września

${ }^{27}$ J. Turek: Biegły sądowy i jego czynności, Monitor Prawniczy 24/2007. Warszawa 2007.

${ }^{28}$ T. Tomaszewski: Dowód z opinii biegłego w procesie karnym, Kraków 1998, s. 9. 
2001 r., o dostępie do informacji publicznej ${ }^{29}$ wnioski do wszystkich Prokuratur Okregowych oraz do wszystkich Komend Wojewódzkich Policji działających na terenie kraju. Wniosek dotyczył pytania, ile w danej jednostce w latach 2014-2016 wszczętych było postępowań dotyczących przestępstw gospodarczych opisanych w rozdziale XXXVI kodeksu karnego ${ }^{30}$ oraz w ilu sprawach powołano biegłego sądowego. Próba badawcza została tak dobrana, ponieważ systemy wymiaru sprawiedliwości nie pozwalają na wyodrębnienie danych dotyczących tylko karuzeli VAT natomiast rozdział XXXVI kodeksu karnego zawiera art. 299 pranie pieniędzy, który zawsze towarzyszy przestępstwom karuzelowym, jak również wszelkim zorganizowanym przestępstwom gospodarczym. W badaniu nie zostały ujęte te jednostki, które w odpowiedzi na wniosek o udzielenie informacji publicznej przekazały, że nie prowadzą statystyk dla biegłych sądowych. Ponadto w zakresie Komend Wojewódzkich przekazane dane dotyczą również jednostek podległych (Komend Miejskich) $\mathrm{z}$ wyjątkiem Komendy Wojewódzkiej Policji w Katowicach, Komendy Wojewódzkiej Policji w Radomiu, Komendy Wojewódzkiej Policji w Gdańsku, Komendy Wojewódzkiej Policji we Włocławku. Natomiast dane Komendy Wojewódzkiej Policji w Kielcach dotyczą okresu od stycznia 2016 do października 2017. Komenda Wojewódzka w Łodzi udostępniła dane dotyczące wszczętych postępowań również w jednostkach podległych jednak dane dotyczące biegłych sądowych dotyczą tylko Komendy Wojewódzkiej. Źródłem otrzymanych danych statystycznych są wskazane w badaniu jednostki. Dane te pochodzą z systemów poszczególnych jednostek i zostały udzielone za okres 2014-2016. Badane jednostki zostały opisane w tabeli 1.

Na podstawie zgromadzonych danych statystycznych za pomocą tabeli 1 wykazano skale współpracy między wymiarem sprawiedliwości, a biegłymi sadowymi. W wielu otrzymanych odpowiedziach na wniosek o udzielenie informacji publicznej jednostki podlegające badaniu wyszczególniało biegłych z dziedziny informatyki i księgowości. Z uwagi na charakter przestępstw opisanych w rozdziale XXXVI kodeksu karnego jest to zrozumiałe.

Tabela1. Skala współpracy biegłych sądowych z wymiarem sprawiedliwości w postępowaniach dotyczących przestępczości gospodarczej.

\begin{tabular}{|l|c|c|}
\hline Badana jednostka & $\begin{array}{c}\text { Ilość przestęstw } \\
\text { gospodarczych }\end{array}$ & $\begin{array}{c}\text { Ilość powołanych } \\
\text { biegłych sądowych }\end{array}$ \\
\hline KWP w Kielcach & 2538 & 697 \\
\hline KWP w Radomiu & 107 & 25 \\
\hline KWP w Łodzi & 18278 & 42 \\
\hline KWP w Gdańsku & 94 & 30 \\
\hline KWP w Szczecinie & 10689 & 1593 \\
\hline KWP w Rzeszowie & 12538 & 12 \\
\hline KWP w Katowicach & 184 & \\
\hline
\end{tabular}

${ }^{29}$ Ustawa z dnia 6 września 2001 r. o dostępie do informacji publicznej. (t.j. Dz. U. z 2016 r. poz. 1764).

${ }^{30}$ Rozdział XXXVI Przestępstwa przeciwko obrotowi gospodarczemu, Ustawa z dnia 6 czerwca 1997 r. Kodeks karny. (t.j. Dz. U. z 2016 r. poz. 1137 z późn. zm.). 


\begin{tabular}{|c|c|c|}
\hline KWP w Opolu & 6298 & 267 \\
\hline KWP w Lublinie & 15606 & 46 \\
\hline KWP w Krakowie & 20720 & 100 \\
\hline Prokuratura Okręgowa w Lublinie & 406 & 171 \\
\hline Prokuratura Okręgowa w Bielsku Białej & 112 & 53 \\
\hline Prokuratura Okręgowa w Opolu & 1216 & 179 \\
\hline Prokuratura Okręgowa we Włocławku & 7 & 22 \\
\hline Prokuratura Okręgowa w Warszawie & 1441 & 190 \\
\hline Prokuratura Okręgowa w Płocku & 61 & 6 \\
\hline Prokuratura Okręgowa w Częstochowie & 286 & 108 \\
\hline Prokuratura Okręgowa w Elblągu & 70 & 36 \\
\hline Prokuratura Okręgowa w Rzeszowie & 821 & 127 \\
\hline Prokuratura Okręgowa w Białymstoku & 893 & 128 \\
\hline
\end{tabular}

Źródło. Opracowanie własne na podstawie danych otrzymanych w ramach dostępu do informacji publicznej z jednostek wskazanych w tabeli 1.

Analiza danych zawartych w tabeli 1 pozwala jednoznacznie stwierdzić, iż mimo, że przestępstwa gospodarcze charakteryzują się dużym stopniem skomplikowania współpraca biegłych sądowych $\mathrm{z}$ wymiarem sprawiedliwości $\mathrm{w}$ prowadzonych postępowaniach jest niewystarczająca. Stanowi ona zaledwie $4,17 \%$ w skali prowadzonych postępowań i dochodzeń karnych. Zważywszy na czas trwania postępowań podatkowych i karnych wydaje się, iż zmiana tego trendu mogłaby znacząco wpłynąć na skrócenie czasu prowadzonego postępowania. Ponadto współpraca z biegłym sądowym zwiększyłaby efektywność w zakresie ustalania faktycznych organizatorów przestępstwa, co w sposób znaczący wpływałoby na odzyskanie przez Budżet Państwa należności publicznoprawnych, a wymiarowi sprawiedliwości umożliwiło realne odzyskanie mienia pochodzącego z przestępstwa. Z punktu widzenia finansów publicznych ustalanie faktycznych organizatorów jest niezbędne.

\section{Podsumowanie}

Konkludując rozważania zawarte w artykule kluczową rolę w ograniczaniu zjawiska przestępstw karuzelowych odgrywa odpowiednie zbieranie i zabezpieczanie materiału dowodowego, ale już na początku postępowania podatkowego zbieranie materiału dowodowego pod kątem ustalania faktycznych organizatorów przestępstwa karuzelowego. Należy również zwiększyć korzystanie ze specjalistycznych analiz kryminalnych przepływów finansowych zorganizowanych grup przestępczych. Analizy takie są sporządzane przy współpracy biegłych z dziedziny informatyki dysponujących specjalistycznym oprogramowaniem IBM i2 Analyst's Notebook oraz biegłych z dziedziny ekonomii specjalizujących się $w$ analizie zorganizowanych grup przestępczych w zakresie przestępczości gospodarczej o czym szerzej autor pisał w 
publikacji pt. Mechanizm przestępstw karuzelowych i metody ich ograniczenia ${ }^{31}$ niniejsza publikacja stanowi rozszerzenie badań zawartych w przywołanym artykule.

Praktyka niestety pokazuje, iż organy ścigania dopiero po trzech do sześciu lat od momentu wszczęcia postępowania zwracają się do biegłego sądowego o analizę zebranego materiału i wskazanie faktycznych sprawców przestępstw podatkowych co z uwagi na upływ czasu prowadzi często do tego, że zebranie materiału dowodowego jest niemożliwe, ponieważ dokumentacja albo uległa przedawnieniu albo została zniszczona. Organy podatkowe przez zabezpieczenie dokumentacji w znikomym zakresie korzystają $\mathrm{z}$ biegłych $\mathrm{z}$ dziedziny informatyki razem $\mathrm{z}$ biegłych $\mathrm{z}$ dziedziny księgowości, którzy $\mathrm{w}$ praktyce używając programów komputerowych księgowych są w stanie na miejscu w podmiocie wyodrębnić dane i zabezpieczyć materiał niezbędny do zweryfikowania czy doszło do popełnionego przestępstwa.

Wyniki przeprowadzonych rozważań wskazują, iż koniecznym jest rekomendowanie stworzenia procedur, które już na samym początku postępowania będą zmierzać do ustalania faktycznych sprawców przestępstwa karuzelowych, co pozwoli na szybkie zakończenie postępowań bez zbędnego oczekiwania na uprawomocnienie się decyzji podatkowych. $Z$ drugiej strony organy podatkowe już wydając decyzje pierwszej instancji powinny zmierzać do wydania decyzji w oparciu o art. 55 kodeksu karnego skarbowego, co pozwoli na wyciagnięcie konsekwencji karnych i podatkowych w stosunku do faktycznego organizatora. Działanie takie pozwoli zastosować konfiskatę rozszerzoną w stosunku do faktycznego organizatora, który jest beneficjentem korzyści finansowych pochodzących z przestępstwa. W rezultacie budżet państwa zyska realną możliwość odzyskania wyłudzonego podatku.

\section{Literatura}

Babiarz S. [w:] Babiarz S., Dauter B., Gruszczyński B., Hauser R., Kabat A., Niezgódka-Medek M., Ordynacja podatkowa. Komentarz, Warszawa 2004

Babiarz S., Dauter B., Gruszczyński B., Hauser R., Kabat A., Niezgódka-Medek M.: Ordynacja podatkowa. Komentarz, Warszawa 2004

Baniak S.: Prawo karne skarbowe. Wolters Kluwer, Warszawa 2006

Hołyst B., Kryminalistyka, LexisNexis, Warszawa 2007.

Keen M., Smith S.: VAT Fraud and Evasion: What Do We Know, and What Can be Done? IMF Working Paper 2007 za: Lipniewicz R., Docelowy system VAT w Unii Europejskiej. Harmonizacja opodatkowania transakcji wewnątrzwspólnotowych, Oficyna 2010, lex/El.

Kozub- Skalska S.: Mechanizm przestępstw karuzelowych i metody ich ograniczenia, Zeszyty Naukowe Szkoły Głównej Gospodarstwa Wiejskiego w Warszawie Polityki Europejskie, Finanse i Marketing nr 17 (66) 2017.

Mastalski R., [w:] Adamiak B., Borkowski J., Mastalski R., Zubrzycki J.: Ordynacja podatkowa. Komentarz 2003, Wrocław 2003

Mastalski R., [w:] Adamiak B., Borkowski J., Mastalski R., Zubrzycki J., Ordynacja podatkowa. Komentarz 2004, Wrocław 2004.

\footnotetext{
${ }^{31}$ Zobacz. Mechanizm przestępstw karuzelowych i metody ich ograniczenia, Zeszyty Naukowe Szkoły Głównej Gospodarstwa Wiejskiego w Warszawie Polityki Europejskie, Finanse i Marketing NR 17 (66) 2017, Warszawa, s. 145-160.
} 
Nowak K.: Wybrane zagadnienia dotyczące działalności tzw. słupów w ramach zorganizowanych grup przestępczych dopuszczających się oszustw podatkowych w związku z obrotem wyrobami stalowymi. Przegląd Bezpieczeństwa Wewnętrznego nr 10 (6) 2014

Nowak K.: Wybrane zagadnienia dotyczące działalności tzw. słupów w ramach zorganizowanych grup przestępczych dopuszczających się oszustw podatkowych w związku z obrotem wyrobami stalowymi. Przegląd Bezpieczeństwa Wewnętrznego nr 10 (6) 2014

Olesińska A. [w:] Brzeziński B., Kalinowski M., Masternak M., Olesińska A., Ordynacja podatkowa. Komentarz, Toruń 2002.

Pabiański T., Śliz W.: Zorganizowane działania przestępcze wykorzystujące mechanizmy konstrukcyjne podatku VAT, Przegląd Podatkowy, 1/2007.

Tomaszewski T.: Dowód z opinii biegłego w procesie karnym, Kraków 1998

Turek J.: Biegły sądowy i jego czynności, Monitor Prawniczy 24/2007.

Ustawa z dnia 10 września 1999 r. Kodeks karny skarbowy. (t.j. Dz. U. z 2016 r. poz. 2137 z późn. zm.).

Ustawa z dnia 29 sierpnia 1997 r. - Ordynacja podatkowa. (t.j. Dz. U. z 2017 r. poz. 201 z późn. zm.).

Ustawa z dnia 6 czerwca 1997 r. Kodeks karny. (t.j. Dz. U. z 2016 r. poz. 1137 z późn. zm.).

Ustawa z dnia 6 września 2001 r. o dostępie do informacji publicznej. (t.j. Dz. U. z 2016 r. poz. 1764).

Wilk L.: Firmanctwo - art. 55 kodeksu karnego skarbowego, Prok. i Pr. 2001 nr 6.

Wilk L.: Firmanctwo - art. 55 kodeksu karnego skarbowego, Prok. i Pr. $2001 \mathrm{nr} 6$

Wilk L.: Przestepstwa i wykroczenia skarbowe [w:] Prawo gospodarcze i handlowe. Tom. 10. Prawo karne gospodarcze, pod redakcją Górniok O., Warszawa 2003

Wyrok Wojewódzkiego Sądu Administracyjnego w Warszawie z dnia 3 lutego 2017 r. III SA/Wa 3363/15 Znikający podatnik, bufor i broker w karuzeli podatkowej.

Zalewski D.: Odpowiedzialność za firmanctwo, Monitor Podatkowy 2009 nr 4, Mastalski R. [w:] Adamiak B., Borkowski J., Mastalski R., Zubrzycki J., Ordynacja podatkowa. Komentarz 2004, Wrocław 2004.

\section{Abstract}

One of the mechanisms that significantly contributes to the existence of the VAT gap are tax frauds implemented within the so-called carousel tax. Unfortunately, the scale of this occurrence shows that both tax authorities and law enforcement agencies do not cope with limiting this scale. This is because in the conducted proceedings, the real organizer of the VAT carousel is often not detected, which in turn means that he is looking for new substituted persons and almost immediately creates a new carousel. According to the author, such a state of affairs corresponds, inter alia, to the tax authority issuing tax decisions on substituted persons, without making use of the possibilities resulting directly from art. 55 of the penal fiscal code (endorsing). It can not be forgotten that the actual beneficiaries of financial benefits from tax frauds are the organizers, not the substitute persons, which as a result of their role are very low paid. Issuing a tax decision on the real organizer makes it possible to regain the actual losses taken by the state budget. In addition, specialized units dealing with the recovery of property, which are subject to the Department of Recovery of Property at the Police Headquarters would have a real chance to secure the property of an organizer from a crime. It seems that without changing the tax authorities' approach and law enforcement cooperation, the real organizers will remain unpunished, and the recovery of assets almost impossible - despite the favorable legislative possibilities. A broad analysis of the criminal procedure pattern is necessary to determine the real organizers, and thus, as the practice shows, closer judicial cooperation with court experts, which in turn will contribute to the effectiveness of identifying the real organizers of organized criminal groups operating in the areas of carousel crimes.

The article is a continuation of the research undertaken by the author in the publication Mechanism of carousel crimes and methods of their limitation.

The aim of the article is to draw attention to the need to change the approach to the conducted proceedings, which can realistically reduce the scale of carousel crimes. At the same time, the author indicates the necessity to use the existing legal status and to cooperate with court experts in order to improve the efficiency of proceedings (duration of proceedings, determination of real 
organizers). The added value of the study is that the methods mentioned in the article do not require legislative changes, so they can be applied immediately in practice. In order to present the intended objectives, there were applied methods of literature research and public data made available by the Ministry of Finance, applicable legal acts. In addition, own research was carried out, including the scale of cooperation between the judiciary and court experts, which allows us to verify the hypothesis that the scope of this cooperation in the field of economic crime is insufficient. The considerations in the article are both theoretical and practical.

Key words: endorisng, VAT carousels, carousel organizers, opinions of court experts.

\section{Informacja o autorze:}

mgr Sonia Kozub - Skalska

Uniwersytet Ekonomiczny w Katowicach

Wydział Finansów i Ubezpieczeń

Katedra Finansów Przedsiębiorstw i Ubezpieczeń Gospodarczych

e-mail: sonia.kozub.skalska@edu.uekat.pl 